International Journal of Instruction e-ISSN: 1308-1470 • www.e-iji.net
July $2020 \bullet$ Vol.13, No.3

p-ISSN: 1694-609X

pp. 445-460

Received: 24/09/2019

Revision: 01/02/2020

Accepted: 06/02/2020

OnlineFirst:29/04/2020

\title{
Insights from Saudi Student Teachers: Successes and Challenges
}

\section{Hiya Almazroa}

Prof., Curriculum and Instruction Dep., College of Education, Princess Nourah bint Abdulrahman University, Saudi Arabia, hmalmazroa@pnu.edu.sa

The goal of this research was to investigate successful experiences and challenges of student teachers during their learning and training period. Participants were student-teachers enrolled in a Primary Grades Teacher Education program at a large women's university. A mixed-method approach was followed, using reflective journals, group interviews, and a survey. The reflective journals were an assigned task in the Student Teaching Seminar on a weekly basis. Interviews included open-ended questions to explore their feelings, opinions, past experiences and expectations. A survey consisted of 16 items was administered to 68 student teachers and comprised of questions in three categories: clinical experiences, collaborative partnership, and clinical educators. Four key factors were identified as successful experiences: having an effective cooperative teacher; learning with peers; Feeling of being a contributor; and learning to understand differences. Three key challenges were identified as follows: lack of support at the field-based school; lack of supervision; and problems with classroom management. Findings demonstrated the importance of seeking trainee teachers' perceptions about their experiences in order to enhance the effectiveness of teaching practicums.

Keywords: student teaching, teacher success, teacher challenges, mixed methods, cooperative teacher, field based school

\section{INTRODUCTION}

Policymakers and practitioners consider practicums the key component of preservice teacher preparation (Education, 2010). Practicums have been seen as a major element of teacher development (L Darling-Hammond \& Baratz-Snowden, 2005), and as having the greatest impact on teacher training quality (Ken Zeichner, 2010). In fact, student teaching is seen as the most likely factor to influence program graduates' ability to improve student outcomes (Princeton, 2010). Cheng, Tang, and Cheng (2016) defined it as "a student learning to teach by applying his/her own learning approach as well as developing his/her conceptions of teaching as preparation for becoming a teacher".

Student teaching has been a discussion focus among teacher educators. Yet, AERA Panel on Research and Teacher Education (Clift \& Brady, 2005) and a report of the 
National Research Council (Council, 2010) pointed, that it is difficult to deduce from the research what influence a specific field experience may have on preservice teachers. The particular ways student teaching contributes to student teachers' development are still uncertain, even in the face of calls for practical pathways. It is implicit in most policies that student teachers learn best from clinical experiences (Bromfenbrennner \& Bronfenbrenner, 1979). Anderson and Stillman (2013) called for research into exactly what constitute a rich practicum experience. Even having (Dewey, 1938) to warn that experience is not always educative and can even be mis-educative - such as practicums which are based on continuous negative, discouraging, or restrictive experiences or in the lack of supervision. Since Dewey's warning, there remains a concern that schoolbased experiences can actually produce damaging socializing consequences, instead of positive outcomes (Kenneth Zeichner \& Gore, 1990).

Power and Bogo ( 2003) suggested that student teaching can be enhanced when student teachers' concerns are addressed and acknowledged. A number of studies of student teaching perspectives on practicums have been carried out. In a regional university in Australia, Wilks, Snow, Lasczik, and Bowling (2019) explored student teacher's perceptions, expectations for, and reflections on their education course through a fouryear longitudinal research, to gather meaningful data other than student evaluation surveys. Student teachers expressed their needs for more behavior management strategies, assessment tasks, and improved university-to-school transitions. Liz and Baxen (2018) analyzed extracts from discussions with student teachers in relation to diversity, using critical theory and the capabilities approach. They found a gap between theories learned at university and reality in schools which resulted in inadequacy of student teachers to deal with disadvantage schools. Van Schagen, and Crosby(2017) explored practicum experiences in an early childhood teacher education program. A questionnaire was used to uncover student teacher's overall practicum experiences. It was found that they had feelings of being energized and relaxed, and feeling of fit with their cooperating teachers, which were positively associated with practicum satisfaction and teacher efficacy. yet some student teachers felt frustrated in their practicum classrooms which were negatively associated with students' fit with their cooperating teacher, satisfaction, and teacher efficacy. In an attempt to describe how student teachers, talk about their early classroom-based experience, thirty-four student teachers in early childhood care and education program were interviewed, answered survey questions, and submitted journals. Analysis are discussed according to two broad themes. First, in terms of how students talk about their experiences, they described their early student teaching experiences as having a sense of belonging and not having a sense of belonging. and second, in terms of what students talk about, which was found to be: communication, support, freedom, learning, and the children (Christine, Karen, and Johnson, 2014). Goh and Matthews (2011) examined fourteen Malaysian student teachers' concerns and experiences during their practicums. Analysis of reflective journal throughout their practicum identified four concerns as follow: classroom management; institutional and personal adjustment; teaching; and student learning. Hanline (2010) identified events of Early Childhood preservice teachers that were seen as influencing their thinking in Special Education. The qualitative study used preservice 
teachers' reflective journals, supervisor notes, and preservice teachers' evaluations of field experience. Analysis showed that the strand of child-focused practices received majority of data, assessment strand was the second largest number of coding, familybased practices strand had the third highest number of coding. From the perspective of Australian pre-service teachers, Moody ( 2009) identified key elements in a positive practicum which are: supervising teacher support, freedom to develop teaching style, constructive feedback, and the approach to assessment.

Mostly, these studies results discussed the challenges the student teachers faced during their process of formation. But these previous studies did not examine in depth the perceptions of student teachers regarding the successes and strengths of their practicums, thus providing ideas about what experiences should be kept and nurtured and which avoided. Hence, this study seeks to look at the whole experience of student teacher practicums, including its challenges as well as strengths. It is essential to study how students interpret and understand what they experience, to understand both their learning as future teachers and specific benefits of the experience. Teachers' beliefs about their readiness for classroom teaching usually has a basis in their classroom-based experiences (Linda Darling-Hammond, Chung, \& Frelow, 2002). Moreover, often practicum reorganizations are imposed from above without looking at the perspectives of student teachers themselves, who are engaged in the experience (Goodson, 2003), and this study will attempt to ensure that bias does not occur.

Examining what contributes to teacher learning in practicum experiences may inspire teacher preparation programs to better provide meaningful learning experiences (Tschannen-Moran \& Hoy, 2001). The current study contributes to enhance the current literature examining the undergraduate practicum experience. The overall purpose of this study is to explore student teachers' perceptions of the successes and challenges that affected their learning opportunities in their field experience in order to increase understanding of the impact of the practicum on student teachers.

Discussions about the practicums are, timely, especially in view of the lack of this specific aspect on teacher education policies in Saudi Arabia. Student teaching is an overlooked/neglected area for Saudi policy makers. Little consideration is devoted to this key phase of student teachers' preparation. Writing on this issue has been limited to identifying problems in practicums. The quality of some practicums can be questionable. Some of the preparatory institutions only provide one month of field experience to student teachers without specifications for roles and responsibilities or identified assessments (Al-Seghayer, 2014; Hamdan, 2015). Faculty members and student teachers' perspectives indicated strengths, challenges, and suggestions regarding student teaching (almazroa,, 2019). This study is a follow-up study, aiming to give a more indepth analysis and to expand the usability of student teachers' perspectives about practicums from different perspectives from different parts of the world. Therefore, this study attempts to answer the following questions: 1) What do student teachers see as successful experiences during student teaching? and 2) What do student teachers see as challenges during student teaching? 


\section{METHOD}

This is a mixed-method study. According to Creswell (2014), "mixed methods research is an approach to inquiry involving collecting both quantitative and qualitative data, integrating the two forms of data". By using a survey, the quantitative study assessed student teachers' perceptions of the practicum. A qualitative approach was required to assess their perceptions by using reflective journals and group interviews. Therefore, in order to corroborate the findings, it was essential to use a mix of both quantitative and qualitative methods (Creswell \& Clark, 2011), which provides a more complete understanding of a research problem than either method alone (Creswell, 2014).

Participants were eligible to participate in the study if they were enrolled in the final student-teaching experience, which was linked to a core course called "Student Teaching Seminar." The students were required to attend a weekly seminar in order to reflect on their practicum setting. Students were required to spend four days per week in their classroom placement. A total of 68 student teachers participated in this study and completed the survey. Nine participants took part in the subsequent phase by providing reflective journals and interviews.

\section{Data Collection}

The primary methods in this study were reflective journals, group interviews, and a survey, as follows:

Reflective journals: The reflective journals were an assigned task in the Student Teaching Seminar to provide participants with the opportunity to set forth their thinking about their practicum on a weekly basis. The journals provided considerable raw material for further analysis (Holly, 1984). Each week of fieldwork, student teachers were required to submit a written reflective journal entry. Each journal entry included a brief description of connection to the program goals, what was learned, and descriptions of feelings, events, and growth in learning to teach.

Group interviews: Interviews were facilitated by the researcher at the end of student teaching, and open-ended questions were used to gather qualitative information about the participant's perceptions by exploring their feelings, opinions, past experiences and expectations. Group interview questions were developed as follows: 1) Describe meaningful learning experiences towards becoming a teacher during your practicum;2) Think about all the practicums during the program and describe which one was the most valuable and why? 3) What were the experiences that you had that stand out most in your mind? and 4) Describe difficulties/challenges you experienced during your practicum.

Instrument tool: The researcher realized the need to provide a numeric description of trends, and opinions of participants (Creswell, 2014). Thus, the study built a survey to collect data, by the end of semester, to offer an indication of the practicum in line with its practices advocated in the literature, specifically as defined by the Council for the Accreditation of Educator Preparation (CAEP, 2013). Thus, the third technique used for data collection was a survey which was administered to 68 student teachers in the final 
field experience. The survey was comprised of questions in three categories: clinical experiences, collaborative partnership, and clinical educators. The survey consisted of 16 items and used the Likert scale (strongly agree $=4$, agree $=3$, disagree $=2$, and strongly disagree $=1$ ). All of the survey statements were written as positive statements. The survey was validated based on input and consensus from nine teacher educators. The reliability was ascertained by test-retest on student participants. Internal Consistency was calculated through Cronbach's Alpha Coefficient 0.88.

Both quantitative and qualitative data were collected concurrently. Creswell (2014) stated that researchers using convergent parallel design conduct studies should collect quantitative and qualitative data at the same time and then analyze these data separately from one another (Teddlie \& Tashakkori, 2009). As discussed by (Brantlinger, Jimenez, Klingner, Pugach, \& Richardson, 2005), the Credibility of the data was determined as follows: 1) Data triangulation, data was collected from three sources: the student teachers' weekly reflective journals, group interviews, and the survey. "The use of multiple data collection methods contributes to the trustworthiness of the datatriangulation" (Glesne \& Peshkin, 1992). 2) Investigator collaborative work - use of several researchers in order to attain interrater reliability checks on the coding of data.

\section{FINDINGS}

The first source of data was the student teachers' weekly reflective journals. A total of 101 journal entries out of 108 entries (12 weeks for nine student teachers) were coded and analyzed. A second source was based on the group interview findings. During the two group interviews (one group of 4 student teachers and the other of 5), a total of eight questions were asked and later coded and analyzed. The third source was a survey for all student teachers graduating that semester. Qualitative and quantitative data were analyzed separately (Creswell \& Clark, 2011). A side-by-side comparison technique was used to merge the results of the qualitative and quantitative data.

\section{Qualitative Results}

The identification of aspects that the participants considered important to student teaching, based on the reflective journals about the practicum, were analyzed utilizing thematic analysis (Braun \& Clarke,2006). Initially, iterations were suppressed. Subsequent and recurrent readings allowed familiarity with and allowed comprehension of student teachers' experiences and perceptions. Next, open and free coding was used to generate common themes that emerged in journals. Then, the data was coded, and connections were made between emerging categories and patterns. Sorting and combining different codes into possible themes established broader themes. The data codes and themes were reviewed, a step that required ensuring that the themes represented the coded data accurately. The coding process added group interview data to be read and coded. The author coded all journals, and the research assistant reexamined them and collaborate on revisions and discussions and therefore a few additional codes were added. At this stage, in-depth descriptions of each theme were written, and quotations from the data were linked to the themes. Categories were consistent across the two coders. Group interviews were analyzed comparatively for 
corresponding themes. Table 1 provides a summary of the concepts identified in the data analysis.

Table 1

Emerging Themes and Codes Represented in Reflective Journals and Group Interviews

\begin{tabular}{lll}
\hline & Codes & Occurrences \\
\hline Emerging themes (positive experiences) & 5 \\
\hline Cooperative & Good rapport with cooperative teachers & 5 \\
teacher (24) & Observing cooperative teachers' teaching practices & 6 \\
& Observing cooperative teachers' behaviors with students & 6 \\
& Receiving continuous guidelines from the cooperative & \\
\hline teachers & 8 \\
peers ( 11) & Cxchanging experiences & 3 \\
\hline Valuable & Participatory role, not observatory role & 4 \\
contribution & Sense of accomplishment & 5 \\
(9) & & \\
\hline Understandin & Recognizing students with learning difficulties & 4 \\
g differences & Differentiating instructions & 3 \\
(7) & & \\
\hline Emerging themes (challenges) & 3 \\
\hline School-based & Work load & 7 \\
environment & Schedules and duties & 4 \\
$(14)$ & No feedback & 3 \\
\hline Classroom & Facing school realities & 5 \\
management & Student discipline & \\
\hline
\end{tabular}

Looking at table (1), it is obvious that the expression "cooperative teacher" appeared the most during data analysis with (24) occurrences, which indicates that CT characteristic as the most influential factor in the success of practicums for student teachers. Also, many student teachers appreciated the benefit of being within a group of student teachers and not being alone in a school and valued the opportunity to participate in teaching and enjoy the participatory role, not just the observatory role. They wrote about their experiences recognizing students with learning difficulties and how they applied different teaching approaches to teach them. Data analysis highlighted varying challenges during student teaching. Although these student teachers compliment their cooperative teachers, they were not satisfied with school based environment.

\section{Quantitative Results}

The mean response by student teachers to the overall rating of the task was 4.05 . Table 2 presents a general picture of the results in respect to three dimensions and shows that "Clinical Experiences" is the greatest area of satisfaction $(M=; 3.32)$. 'Collaborative partnerships" with schools' sub-scale revealed medium satisfaction $(M=, 2.95)$, which indicated positive influence of the student teaching experiences on student teachers' learning. Despite these findings, the student teachers' perceptions concerning the 
"Clinical educators" are less positive. The lower mean rates on this sub-scale $(\mathrm{M}=$ ,2.72) reveal the dissatisfaction felt by many of these student teachers.

Table 2

Student Teachers' Perceptions during Practicum

\begin{tabular}{|c|c|c|c|c|c|c|c|c|}
\hline \multicolumn{3}{|c|}{ Clinical experience } & High & Med & Low & Non & $M$ & $S D$ \\
\hline \multirow[t]{2}{*}{1} & \multirow{2}{*}{$\begin{array}{l}\text { I gain fruitful experiences during } \\
\text { practicum. }\end{array}$} & $N$ & 54 & 14 & 0 & 0 & 3.79 & 0.41 \\
\hline & & $\%$ & 79.4 & 20.6 & 0 & 0 & & \\
\hline \multirow[t]{2}{*}{2} & \multirow{2}{*}{$\begin{array}{l}\text { In practicum, I apply what I learn in } \\
\text { program courses. }\end{array}$} & $N$ & 47 & 19 & 2 & 0 & 3.66 & 0.54 \\
\hline & & $\%$ & 69.1 & 27.9 & 2.9 & 0 & & \\
\hline \multirow[t]{3}{*}{3} & \multirow{3}{*}{$\begin{array}{l}\text { Being with my colleagues in the same } \\
\text { school was a major support for me. }\end{array}$} & $N$ & 43 & 19 & 4 & 2 & 3.51 & 0.74 \\
\hline & & $\%$ & 63.2 & 27.9 & 5.9 & 2.9 & & \\
\hline & & $\%$ & 57.4 & 32.4 & 8.8 & 1.5 & & \\
\hline \multirow[t]{2}{*}{4} & \multirow{2}{*}{$\begin{array}{l}\text { There is clarity of practicum goals and } \\
\text { expectations. }\end{array}$} & $N$ & 32 & 30 & 6 & 0 & 3.38 & 0.65 \\
\hline & & $\%$ & 47.1 & 44.1 & 8.8 & 0 & & \\
\hline \multicolumn{9}{|c|}{ Collaborative partnerships with schools } \\
\hline \multirow[t]{2}{*}{5} & \multirow{2}{*}{$\begin{array}{l}\text { Schools are equipped with teaching } \\
\text { resources. }\end{array}$} & $N$ & 35 & 15 & 15 & 3 & & \\
\hline & & $\%$ & 51.5 & 22.1 & 22.1 & 4.4 & 3.21 & 0.94 \\
\hline \multirow[t]{2}{*}{6} & \multirow{2}{*}{$\begin{array}{l}\text { School helps in solving problems I face } \\
\text { during teaching practicum. }\end{array}$} & $N$ & 15 & 27 & 16 & 10 & & \\
\hline & & $\%$ & 22.1 & 39.7 & 23.5 & 14.7 & 2.69 & 0.98 \\
\hline \multirow[t]{2}{*}{7} & \multirow{2}{*}{$\begin{array}{l}\text { There is coordination between school } \\
\text { and university regarding cooperative } \\
\text { teacher's task. }\end{array}$} & $N$ & 18 & 19 & 19 & 12 & & \\
\hline & & $\%$ & 26.5 & 27.9 & 27.9 & 17.6 & 2.63 & 1.06 \\
\hline \multirow[t]{3}{*}{8} & \multirow{2}{*}{$\begin{array}{l}\text { There is direct connection between } \\
\text { schools and university. }\end{array}$} & $N$ & 10 & 6 & 16 & 36 & & \\
\hline & & $\%$ & 14.7 & 8.8 & 23.5 & 52.9 & 1.85 & 1.10 \\
\hline & Clinical Educators & & High & Med & Low & Non & $M$ & $S D$ \\
\hline \multirow[t]{2}{*}{9} & \multirow{2}{*}{$\begin{array}{l}\text { Cooperative teachers have adequate } \\
\text { teaching skills. }\end{array}$} & $N$ & 28 & 24 & 12 & 4 & 3.12 & 0.91 \\
\hline & & $\%$ & 41.2 & 35.3 & 17.6 & 5.9 & & \\
\hline \multirow[t]{2}{*}{10} & \multirow{2}{*}{$\begin{array}{l}\text { The cooperative teacher shared } \\
\text { constructive feedback. }\end{array}$} & $N$ & 28 & 22 & 12 & 6 & 3.06 & 0.98 \\
\hline & & $\%$ & 41.2 & 32.4 & 17.6 & 8.8 & & \\
\hline \multirow[t]{2}{*}{11} & \multirow{2}{*}{$\begin{array}{l}\text { The cooperative teacher has the } \\
\text { knowledge and instructional-skills. }\end{array}$} & $N$ & 26 & 25 & 8 & 9 & 3.00 & 1.02 \\
\hline & & $\%$ & 38.2 & 36.8 & 11.8 & 13.2 & & \\
\hline \multirow[t]{2}{*}{12} & \multirow{2}{*}{$\begin{array}{l}\text { The cooperative teacher provided } \\
\text { professional mentoring. }\end{array}$} & $N$ & 17 & 24 & 16 & 11 & 2.69 & 1.03 \\
\hline & & $\%$ & 25.0 & 35.3 & 23.5 & 16.2 & & \\
\hline \multirow[t]{2}{*}{13} & \multirow{2}{*}{$\begin{array}{l}\text { The university supervisor gave me } \\
\text { feedback to improve my teaching skills. }\end{array}$} & $N$ & 23 & 16 & 16 & 13 & 2.72 & 1.13 \\
\hline & & $\%$ & 33.8 & 23.5 & 23.5 & 19.1 & & \\
\hline \multirow[t]{2}{*}{14} & The university supervisor works with & $N$ & 17 & 14 & 13 & 24 & 2.35 & 1.21 \\
\hline & & $\%$ & 25.0 & 20.6 & 19.1 & 35.3 & & \\
\hline
\end{tabular}

\section{DISCUSSION}

To answer the first research question (What do student teachers see as successful experiences during student teaching?), four themes were identified as follow:

Theme one: Effective cooperative teacher: The expression "cooperative teacher" (CT) appeared the most during data analysis which indicates that CT characteristic is the most 
influential factor in the success of practicums for student teachers. Almost all student teachers informed to have a good rapport with their (CT). The qualitative analysis showed that CT helped student teachers to adjust to the school environment, introduced them to other teachers, and always consulted with them regarding teaching duties. Furthermore, student teachers received continuous guidelines from the CT related to lesson plans, instruction, and other teaching matters.

These findings are apparent in the quantitative data as well (Table 2) where the majority of the student teachers reported positive perceptions of the cooperative teachers. They strongly agreed $(41.2 \%)$ and agreed ( $35.3 \%)$ with the statement, "The cooperative teacher has adequate teaching skills." They also strongly agreed (41.2\%) and agreed $(32.4 \%)$ with the statement number 10 , and strongly agreed $(38.2 \%)$ and agreed $(36.8 \%)$ with the statement, 11 .

Previous research has found that professional identities grow substantially when positive relationships are formed between student teachers and their cooperating teachers (Draves, 2008), and a stronger commitment to teaching results when student teachers receive support from mentors (Guarino, Santibanez, \& Daley, 2006). This study echoes the findings of previous research that are concerned with selection and preparation of cooperating teachers. Building on Zeichner's call for a reconceptualization of the cooperating teacher's role, there is a need to move from traditional student teaching with its central goal of mastering skills to a broader definition that includes shared learning, and collaborative planning, teaching, and reflection. All these elements that have been identified as effective mentoring practices (P. D. Tomlinson, Hobson, \& Malderez, 2010). Universities and schools should coordinate to find a mutual relationship that will benefit both institutions. One new coaching approach being researched is to consider offering credit to cooperative teachers who are seeking Master's degrees or counting student teaching as professional development for cooperative teachers (Gallo-Fox \& Scantlebury, 2016; Guise, Habib, Thiessen, \& Robbins, 2017; Soslau, Kotch-Jester, Scantlebury, \& Gleason, 2018).

Theme two: Learning with peers : Many student teachers appreciated the benefit of being within a group of student teachers and not being alone in a school. This was very clear in their survey response where they strongly agreed $(63.2 \%)$ with the statement, "Being with my colleagues in the same school was a major support for me." In the qualitative analysis, they emphasized the significance of exchanging experiences with peers to help them overcome difficult times, especially at the beginning of student teaching. Exchanging experiences varied in meaning, but it included exchanging ideas, feelings, and even teaching materials. For example, one participant wrote that "we always talked about the next lesson and ways to plan for it during school time and even when they met outside schools". When it comes to collaborative learning, the student teachers seemed to follow a peer-coaching approach to improving their teaching competencies.

These findings are also affirmed in the literature. Student teachers search for and find support from their peers such as sharing material, discussing the needs of pupils, planning and designing lessons, giving feedback, discussing theoretical concepts and 
problems, and providing emotional support (Baeten \& Simons, 2014). Clement and Vandenberghe (2000) pointed out that "collegiality is often considered a necessary condition for professional development". Hauge and Wittek (2003) indicated the merit of having groups of student teachers in schools, since they appreciate collaborative learning, particularly as collaborative planning and joint work has been included in the role of the teacher (Hargreaves, 2000). This social relationship could be a source of coping strategies for student teachers as (Paquette \& Rieg, 2016) found that sources of stress include managing time, teaching workload, and discipline.

Theme three: Feeling of being a contributor: Student teachers valued the opportunity to participate in teaching the youngsters and seeing the impact on their learning. They enjoy the participatory role, not just the observatory role. Participants expressed pride about practicing teachers' full duties for a semester, and most expressed positive perceptions regarding their growing knowledge and skillfulness. Quantitative findings support the qualitative findings. When student teachers were asked to provide their perceptions regarding the statement, "I gain fruitful experiences during practicum," the majority of the participants $(79.4 \%)$ strongly agreed.

Teaching practice is the stage where the mastery of a teacher development faster than at any other stage of their professional development (Capel, Leask, Turner, \& Heilbronn, 2004). Contrasting with the stress and difficulties that student teachers feel during practicum, this sense of accomplishment and satisfaction could be attributed to student teachers' experiences, and, therefore, self-efficacy could be examined as a related research interest.

Theme four: Understanding differences: Data analysis highlighted varying experiences related to student teachers' understanding of differences between the youngsters and efforts to teach them accordingly. Almost all the nine of the student teachers who participated in the qualitative portion study wrote about their experiences recognizing students with learning difficulties and how they applied different teaching approaches to teach them. One participant wrote, "I was able to apply observation and interview techniques I have learned, I was very excited at my own abilities.". Quantitative findings further explain this qualitative finding: to the survey statement, "In practicum I apply what I learn in program courses", $69.1 \%$ of respondents strongly agreed and $27.9 \%$ agreed.

The movement to differentiate instructions in the general education classroom has gained increasing momentum internationally (Tomlinson, 2014). This has been reflected in teacher education programs to improve the quality of the preparation that teacher candidates receive on instruction that effectively responds to academic diversity. It seems that learning in teacher education program prepared the participants to effectively use differentiated instruction. Although differentiated instructions are highly valued, teacher educators need to be aware of the many constraints that student teachers face and place realistic expectations on what student teachers can reasonably implement during teaching practicum. 
When it comes to the second research question (What do student teachers see as challenges during student teaching?), the following themes were identified:

Theme five: School-based environment: Although these student teachers compliment their cooperative teachers, they were not satisfied with other teachers and school faculties. Student teachers stated that other teachers refused to let them teach their classes or allow them to observe them teaching and, thus, gain experience from different teachers and classes. The student teachers felt they were limited to the experience of only one or two teachers during the whole semester. They also felt that the school administration had no role in advocating for them and making sure that they had enough time to prepare for and perform their duties. On the contrary, student teachers said that they were enlisted as substitute teachers, which they considered as extra duties for student teachers.

This situation is reported in other practicum programs around the world. For example, in Malawi, student teachers also faced this dilemma during teaching practicum (Malika, online), and in England, student teachers can be used as supply teachers, instead of supporting them to address their developmental needs. This use of student teachers' time contributes significantly to the problem of excessive workload that has been identified by the research as one of many stressors on student teachers (Klassen et al., 2013).

Looking at quantitative analysis, $23.5 \%$ disagreed and $14.7 \%$ strongly disagreed with the statement, "School helps in solving problems I face during teaching practicum." When it comes to some services that schools provide to student teachers, there seems to be a challenge for student teachers. A total of $25.0 \%$ strongly disagreed and $14.7 \%$ disagreed with the statement, "School provides a place for student teachers." These results indicated that the field school is not engaged in the development of student teachers. The findings in the present study also suggested there is not shared responsibility between schools and universities in preparing teachers. Similar results are reflected in other research studies. The school's acceptance of and provision for satisfactory conditions for student teachers may determine their sense of their selffulfillment regarding the teaching profession (Krečič \& Grmek, 2008). Ronfeldt and Reininger (2012), drawing on survey data from over 1000 preservice teachers in the United States, found that, the quality of teacher placement, not the span of time, has significant effects on teacher outcomes. There is a demand for improved school-based professional support, the professional support offered to student teachers by school staff was the most outstanding positive experience of the trainee teachers (Marais and Meier (2004). Based on these findings, it is important for teacher programs to form a partnership with schools to improve the quality of teacher (Godinho, White, Hay, and St Leger(2007) ; and Zeichner, 2010). Such "hybrid spaces", as mentioned by Gopinathan et al. (2009), are useful for authentic learning. The school settings have a significant impact on student teachers (Hauge \& Wittek, 2003; Ronfeldt, 2012; Kenneth Zeichner \& Gore, 1990).

Theme six : Absences of supervisor's role: The university supervisor's influence in the journals' data was absent, except for negative comments. Student teachers had high expectations of their university supervisors, and a number of comments pointed out their 
absence in developing student teachers' teaching skills. One participant commented, "I expected her to help me, not evaluate me." This agreed with the results of the quantitative analysis where student teachers strongly disagreed (35.3\%) and disagreed $(19.1 \%)$ with the statement, "The university supervisor works with the cooperative teacher and school to facilitate my training", This result is also consistent with Alsulami (2016) conclusion that supervisors don't play effective roles during teaching practicums, as seen by Arabic language student teachers.

Previously, Caires and Almeida (2007) findings agreed with this study finding. They emphasized the important role of the supervisor as key facilitator of the transition of student teachers from learners to professional teachers. The findings of this study are significant since they highlight gaps in the traditional triadic structure of the practicum, demonstrating that the role of the university supervisor is missing. This is important to investigate since Bullough Jr et al. (2002), Mitchell, Clarke, and Nuttall (2007) argued that the practicum can be a weak exercise, without explicit attention from university supervisors and cooperating teachers in the fulfillment of their roles.

Theme seven : Classroom management :Classroom management was one of the challenges faced by student teachers. Student teachers were surprised by the reality of classrooms and struggled with being the one responsible to handle all the youngsters' needs and learning. Student teachers' perceptions of the difficulties of managing classrooms was evident in their preference for the course "Classroom Management." When asked which course they benefited the most from during their university program, seven of the nine listed "Classroom Management." So, this course, which takes place at the teacher education institution, was perceived to contribute mainly in terms of planning, arranging, and encouraging children to interact and learn effectively.

These results are similar to other studies that showed that student teachers felt stressed about classroom management and discipline issues (Chaplain, 2008; Vesely, Saklofske, \& Nordstokke, 2014). This scenario was also apparent in a study by Faizah (2008), where student teachers had problems with disruptive behaviors and class control. Other studies showed that discipline had been identified as one of the most prevalent problems experienced (Page, 2008), and classroom management was the most worrisome subject (Goh \& Matthews, 2011). In addition, student teachers considered classroom management as key areas of knowledge for student teachers (Hourigan \& Scheib, 2009). Also, Draves (2013) pointed out that classroom management as a key area for growth with student teachers.

\section{CONCLUSION}

The voice of student teachers themselves and their description of day-to-day realities within the school are less often heard in the literature and studying their views about their own practicum experiences should benefit towards a greater understanding of the practicum's effectiveness. Especially that teaching practicums are the most powerful influence in pre-service teacher education (Bullough $\mathrm{Jr}$ et al., 2002) and have been considered one of the most influential aspects of pre-service teacher education (Guyton, 1989; Hauge \& Wittek, 2003). The current study provided an understanding of student 
teachers' experiences, and its findings point to the significance of understanding practicum experiences in terms of what factors contribute to teacher learning. Seven key issues emerged. Four issues represent successful practices that should be kept and nurtured: and three issues should be considered for improvement. It is time for teacher education programs to ask how young educators are prepared to face challenges every day as classroom teachers. This study adds to the growing body of research examining features of teacher education by examining institutions that prepare teachers. This study's findings stimulated debate on the practicum experience and, in particular, on the specific areas outlined to improve the practicum. The take-home points are fourfold:

(1): Challenges reported in this study emphasized previous research that showed that teaching workload and classroom management were high stressors for pre-service teachers (Klassen et al., 2013; Skaalvik \& Skaalvik, 2015; Vesely et al., 2014). However, positive experiences that strengthen practicums need to be examined and highlighted in different programs, and models developed in order to elevate learning and utilize resources for improvement.

(2): Teacher educators must recognize the issues of practicum students. Further in-depth studies, as well as, perhaps a larger study through different data collection techniques of the practicum students could be conducted to identify issues of concern regarding the practicum from student teachers' perspectives.

(3): The current study looked at primary grade program, it would be wise to look at other teacher program practicum to help determine what is necessary for student teachers to come to an understanding of their needs. Recommendations for future studies include a wider population, in terms of number of participants' various content areas of student teachers other than primary grade teachers. Ismail and Jarrah (2019) indicated that elementary and early childhood student teachers faced different levels of difficulties during practicum.

(4): The scale has not been validated in other teacher educational contexts in different regions. Accordingly, further studies in different contexts are recommended to validate the measures.

In sum, the findings demonstrated the importance of seeking trainee teachers' perceptions about their experiences in order to enhance the effectiveness of teaching practicums, and the issues raised here can shape debates on the kind of measures that could be adopted.

\section{Acknowledgement:}

This research was funded by the Deanship of Scientific Research at Princess Nourah bint Abdulrahman University through the Fast-track Research Funding Program. 


\section{REFERENCES}

Al-Seghayer, K. (2014). The actuality, inefficiency, and needs of EFL teacherpreparation programs in Saudi Arabia. International Journal of Applied Linguistics and English Literature, 3(1), 143-151.

Alsulami, M. (2016). Arabic language student teacher perceptions towards the effectiveness of university supervisors, cooperating teachers, and school principals during the teaching practicum (Unpublished doctoral dissertation). Southern Illinois University Carbondale. USA.

Almazroa, H. (2019). Evaluation of student teaching in 1-3 grades teacher program. Journal of Educational and Psychology Sciences, Accepted for Publication.

Anderson, L., \& Stillman, J. (2013). Student teaching's contribution to preservice teacher development: A review of research focused on the preparation of teachers for urban and high-needs contexts. Review of Educational Research, 83(1),. 3-69.

Brantlinger, E., Jimenez, R., Klingner, J., Pugach, M., \& Richardson, V. (2005). Qualitative studies in special education. Exceptional children, 71(2), 195-207.

Bromfenbrennner, U., \& Bronfenbrenner, U. (1979). Ecology of human development: Experiments by nature and design. Cambridge: Harvard University

Bullough Jr, R., Young, J., Erickson, L., Birrell, J., Clark, D., Egan, M., Smith, G. (2002). Rethinking field experience: Partnership teaching versus single-placement teaching. Journal of Teacher Education, 53(1), 68-80.

CAEP. (2013). CAEP Accreditation Standards. Council for the Accreditation of Educator Preparation.

Caires, S., Almeida, L., \& Vieira, D. (2012). Becoming a teacher: Student teachers' experiences and perceptions about teaching practice. Journal of Teacher Education, 35(2), 163-178.

Capel, S., Leask, M., Turner, T., \& Heilbronn, R. (2004). Starting to teach in the secondary school: A companion for the newly qualified teacher: Psychology Press.

Chaplain, R. (2008). Stress and psychological distress among trainee secondary teachers in England. Educational Philosophy and Theory, 28(2), 195-209.

Cheng, A., Tang, S., \& Cheng, M. (2016). Changing conceptions of teaching: A fouryear learning journey for student teachers. Teachers and teaching, 22(2), 177-197.

Christine, M., Karen, M., and Johnson, A. (2014). Before student teaching: How undergraduate students in early childhood teacher preparation programs describe their early classroom-based experience. Journal of Early Childhood Teacher Education, 35, 244-261.

Clement, M., \& Vandenberghe, R. (2000). Teachers' professional development: a solitary or collegial (ad) venture? Teaching and Teacher Education, 16(1), 81-101. 
Creswell, J. (2014). Research design: Qualitative, quantitative, and mixed methods approaches: Sage publications.

Creswell, J., \& Clark, V. (2011). Designing and conducting mixed methods research: Sage publications.

Darling-Hammond, L., \& Baratz-Snowden, J. (2005). A good teacher in every classroom: Preparing the highly qualified teachers our children deserve. San Francisco, CA: Jossey-Bass.

Darling-Hammond, L., Chung, R., \& Frelow, F. (2002). Variation in teacher preparation: How well do different pathways prepare teachers to teach? Journal of Teacher Education, 53(4), 286-302.

Dewey, J. (1938). Experience and education.

Draves, T. (2008). "Firecrackers" and "duds" cooperating music teachers' perspectives on their relationships with student teachers. Journal of Music Teacher Education, 18(1), 6-15.

Draves, T. (2013). Transition from student to teacher-student teaching: The capstone experience. Journal of Music Teacher Education, 23(1), 50-62.

Faizah, A. (2008). The use of reflective journals in outcome-based education during the teaching practicum. Malaysian Journal of ELT Research, 4(1), 11.

Gallo-Fox, J., \& Scantlebury, K. (2016). Coteaching as professional development for cooperating teachers. Teaching and Teacher Education, 60, 191-202.

Goh, P., \& Matthews, B. (2011). Listening to the concerns of student teachers in Malaysia during teaching practice. Australasian Journal of Teacher Education, 36(3), 12.

Goodson, I. (2003). Professional knowledge, professional development. Maidenhead: Open University Press.

Gopinathan, S., Tan, S., Yanping, F., Devi, L., Ramos, C., \& Chao, E. (2009). Transforming teacher education: Redefined professionals for 21st century schools. 10.

Groundwater-Smith, S., Ewing, R., \& Le Cornu, R. (2006). Behaving ethically. Teaching: challenges and dilemmas, 331-345.

Guarino, C., Santibanez, L., \& Daley, G. (2006). Teacher recruitment and retention: A review of the recent empirical literature. Review of Educational Research, 76(2), 173208.

Guise, M., Habib, M., Thiessen, K., \& Robbins, A. (2017). Continuum of co-teaching implementation: Moving from traditional student teaching to co-teaching. Teaching and Teacher Education, 66, 370-382.

Guyton, E. (1989). Guidelines for developing educational programs for cooperating teachers. Action in teacher Education, 11(3), 54-58. 
Hamdan, A. (2015). Challenges and constraints encountered by Saudi pre-service science teachers: A critical perspective. Learning Education in Higher Education: Gulf Perspective, 12(1).

Hanline, M. (2010). Preservice teachers' perceptions of field experiences in inclusive preschool settings: Implications for personnel preparation. Teacher Education and Special Education, 33(4), 335-351.

Hargreaves, A. (2000). Four ages of professionalism and professional learning. Teachers and teaching, 6(2), 151-182.

Holly, M. (1984). Keeping a personal-professional journal: Hyperion Books.

Hourigan, R., \& Scheib, J. (2009). Inside and outside the undergraduate music education curriculum: Student teacher perceptions of the value of skills, abilities, and understandings. Journal of Music Teacher Education, 18(2), 48-61.

Ismail, S., \& Jarrah, A. (2019). Exploring Pre-service teachers' perceptions of their pedagogical preferences, teaching competence and motivation. International Journal $f$ Instruction, 12(1), 493-510. https://doi.org/10.29333/iji.2019.12132a.

Klassen, R., Wilson, E., Siu, A., Hannok, W., Wong, M., Wongsri, N., Jansem, A. (2013). Preservice teachers' work stress, self-efficacy, and occupational commitment in four countries. European journal of psychology of education, 28(4), 1289-1309.

Mitchell, J., Clarke, A., \& Nuttall, J. (2007). Cooperating teachers' perspectives under scrutiny: A comparative analysis of Australia and Canada. Asia-Pacific Journal of Teacher Education, 35(1), 5-25.

National Research Council (2010). Preparing teachers: Building evidence for sound policy.

Orland-Barak, L., \& Yinon, H. (2005). Sometimes a novice and sometimes an expert: Mentors' professional expertise as revealed through their stories of critical incidents. Oxford Review of Education, 31(4), 557-578.

Page, S. (2008). The difference: How the power of diversity creates better groups, firms, schools, and societies-new edition: Princeton University Press.

Princeton, N. (2010). Where we stand on teacher quality: An issue paper from ETS. 3.

Ronfeldt, M. (2012). Where should student teachers learn to teach? Effects of field placement school characteristics on teacher retention and effectiveness. Educational Evaluation and Policy Analysis, 34(1), 3-26.

Ronfeldt, M., \& Reininger, M. (2012). More or better student teaching? Teaching and Teacher Education, 28(8), 1091-1106.

Skaalvik, E., \& Skaalvik, S. (2015). Job satisfaction, stress and coping strategies in the teaching profession-what do teachers say? International Education Studies, 8(3), 181192. 
Soslau, E., Kotch-Jester, S., Scantlebury, K., \& Gleason, S. (2018). Coteachers' huddles: Developing adaptive teaching expertise during student teaching. Teaching and Teacher Education, 73, 99-108.

Teddlie, C., \& Tashakkori, A. (2009). Foundations of mixed methods research: Integrating quantitative and qualitative approaches in the social and behavioral sciences: Sage.

Tomlinson, C. A. (2014). The differentiated classroom: Responding to the needs of all learners: ASCD.

Tomlinson, P. D., Hobson, A. J., \& Malderez, A. (2010). Mentoring in teacher education. In P. L. Peterson, E. Baker, \& B. McGaw (Eds.), International encyclopedia of education (pp. 749-756). Amsterdam: Elsevier.

Tschannen-Moran, M., \& Hoy, A. (2001). Teacher efficacy: Capturing an elusive construct. Teaching and Teacher Education, 17(7), 783-805.

Van Schagen, J., La Paro, K., \& Crosby, D. (2017). Early practicum experiences: preservice early childhood students' perceptions and sense of efficacy. Early Childhood Education Journal, 45(2), 229-236.

Vesely, A., Saklofske, D., \& Nordstokke, D. (2014). EI training and pre-service teacher wellbeing. Personality and Individual Differences, 65, 81-85.

Wilks, J. L., Snow, M., Lasczik, L., \& Bowling, A. (2019). Working towards 'doing it better': Seeking the student voice in teacher education. Australian Journal of Teacher Education, 44(1). Retrieved from https://ro.ecu.edu.au/ajte/vol44/iss1/5

Zeichner, K. (2010). Rethinking the connections between campus courses and field experiences in college-and university-based teacher education. Journal of Teacher Education, 61(1-2), 89-99.

Zeichner, K., \& Gore, J. (1990). Teacher socialization. In W. R. Houston (Ed.), Handbook of research on teacher education (pp. 329-348). New York: Macmillan. 